\title{
PENERAPAN MODEL PROBLEM BASED LEARNING UNTUK MENINGKATKAN AKTIVITAS DAN PRESTASI BELAJAR AKUNTANSI
}

\author{
Oleh : \\ Choirun Nisak ${ }^{1}$ \\ Annisa Ratna Sari ${ }^{2}$
}

\begin{abstract}
Abstrak
Penelitian ini bertujuan untuk meningkatkan Aktivitas dan Prestasi Belajar Akuntansi dengan implementasi model Problem Based Learning.Penelitian ini termasuk jenis penelitian tindakan kelas (Classroom Action Research) dengan subjek penelitian siswa kelas X AK 3 SMK Muhammadiyah 2 Klaten Utara Tahun Ajaran 2012/2013 yang berjumlah 19 siswa. Penelitian ini dilaksanakan dalam dua siklus dan setiap siklus memiliki empat tahap pelaksanaan yaitu perencanaan, pelaksanaan, observasi, dan refleksi. Instrumen penelitian berupa: lembar observasi Aktivitas Belajar siswa, catatan lapangan, soal pre-testsertaposttest, dan dokumentasi. Teknik analisis data dalam penelitian ini adalah deskriptifkualitatif. Indikator keberhasilan yaitu Aktivitas Belajardalam pembelajaran dengan model Problem Based Learningmencapai75\% untuk setiap siswa dan $75 \%$ dari jumlah siswa dan Prestasi Belajar Akuntansi mencapai nilai KKM yaitu 75 sebanyak $75 \%$ dari jumlah siswa.Hasil penelitian menunjukkan bahwa Akitvitas dan Prestasi Belajar siswa dapat meningkat setelah diberi tindakan.Pada pra siklus hanya terdapat satu aspek Aktivitas Belajar siswa yaitu menjawab pertanyaan sebesar $15,79 \%$, pada siklus I yang menunjukkan Aktivitas Belajar sebanyak 36,84\% siswa, pada siklus II sebanyak89,47\% siswa. Prestasi Belajar Akuntansi siswa pra siklus menunjukkan yang mendapat nilai $\geq 75$ atau mencapai KKM adalah 9 siswa atau 47\%, pada siklus I Prestasi Belajar Akuntansi siswa yang mendapat nilai $\geq 75$ atau mencapai KKM adalah 16 siswa atau $84,21 \%$, pada siklus II Prestasi Belajar Akuntansi siswa yang mendapat nilai $\geq 75$ atau mencapai KKM adalah 19 siswa atau $100 \%$.
\end{abstract}

Kata-kata kunci: Problem Based Learning, Aktivitas Belajar, Prestasi Belajar Akuntansi

\section{A. Pendahuluan}

Perkembangan ilmu pengetahuan dan teknologi yang semakin pesat mengakibatkan perubahan-perubahan di berbagai bidang kehidupan masyarakat. Perubahan tersebut juga terjadi pada bidang pendidikan. Bidang pendidikan memegang peranan penting bagi kehidupan masyarakat, dimana pendidikan merupakan wadah dalam mencetak sumber daya manusia yang berkualitas yang nantinya dapat turut serta memajukan bangsa.

\footnotetext{
${ }^{1}$ Alumni Prodi Pendidikan Akuntansi Fakultas Ekonomi Universitas Negeri Yogyakarta ${ }^{2}$ Staf Pengajar Jurusan P. Akuntansi Fakultas Ekononi Universitas Negeri Yogyakarta
} 
Mutu pendidikan menekankan pada cara guru dalam mengajar di kelas sehingga siswa aktif dalam setiap pembelajaran. Kualitas pembelajaran dapat dilihat dari aspek proses dan aspek hasil. Proses pembelajaran dikatakan berhasil apabila selama kegiatan pembelajaran siswa menunjukkan aktivitas belajar yang tinggi dan terlihat secara aktif baik fisik maupun mental. Sedangkan kualitas pembelajaran dari aspek hasil dapat dilihat apabila terjadi perubahan perilaku yang positif pada siswa serta menghasilkan keluaran dengan prestasi belajar yang tinggi.

SMK Muhammadiyah 2 Klaten Utara merupakan salah satu Sekolah Menengah Kejuruan (SMK) yang ada di daerah Klaten. SMK Muhammadiyah 2 Klaten Utara memiliki beberapa program keahlian salah satunya adalah Program Keahlian Akuntansi. Program ini terdiri dari 3 kelas X, 2 kelas XI, dan 2 kelas XII.

Fakta observasi pada pra penelitian untuk pembelajaran Akuntansi di SMK Muhammadiyah 2 Klaten Utara kelas X AK 3 pada bulan September 2012 menunjukkan bahwa siswa terlihat kurang aktif. Hal ini ditandai dengan hanya 2 atau 3 siswa dari 19 jumlah siswa yang aktif dalam proses pembelajaran. Sementara siswa lain hanya duduk diam atau menulis, sambil mendengarkan penjelasan dari guru.Sebagian siswa membawa buku paket dari perpustakaan sekolah, karena sekolah tidak menyediakan LKS atau buku paket untuk masing-masing siswa, sehingga siswa lebih sering mendengarkan penjelasan guru.

Wawancara pra penelitian dengan siswa-siswa kelas $\mathrm{X}$ SMK Muhammadiyah 2 Klaten Utara diperoleh informasi bahwa pada pembelajaran Akuntansi, mereka hanya mendengarkan dan mencatat konsep-konsep Akuntansi dan terkesan hafalan. Fakta pra penelitian juga menunjukkan bahwa Prestasi Belajar yang dicapai oleh siswa kelas X AK 3 dalam pelajaran Akuntansi juga kurang memuaskan. Hasil ulangan harian siswa mencapai ratarata kelas sebesar 58 yang berarti belum mencapai kriteria ketuntasan minimal (KKM) yang telah ditentukan oleh sekolah yaitu 75. Persentase keberhasilan kelas sebesar 47\% yaitu hanya 9 dari 19 siswa yang telah mencapai KKM

Solusi yang ditawarkan oleh peneliti adalah pengimplementasian model Problem BasedLearning.Model Problem Based Learning memiliki keunggulan diantaranya dapat meningkatkan Aktivitas siswa dan membantu mentransfer pengetahuan siswa untuk memahami masalah dalam kehidupan nyata, sehingga penyelesaian masalah dapat mendorong untuk melakukan evaluasi diri baik terhadap hasil maupun proses belajarnya (Wina Sanjaya, 2010: 220). Dalam hal ini model Problem Based Learning bukanlah sekedar pembelajaran yang dipenuhi dengan latihan-latihan saja, tetapi dalam Problem Based Learning siswa dihadapkan dengan permasalahan yang membangkitkan rasa keingintahuan untuk melakukan penyelidikan baik secara individu maupun berkelompok sehingga dapat menemukan sendiri jawabannya, dan mengemukakan hasilnya pada orang lain (Setyorini, 2011: 75).

Model pembelajaran Problem Based Learning dapat diterapkan dalam pembelajaran Akuntansi, mengingat dalam proses pembelajaran Akuntansi siswa dihadapkan langsung pada masalah-masalah atau kasus-kasus riil dalam kehidupan sehari-hari baik di dunia usaha maupun dunia industri. Penerapan 
model pembelajaran Problem Based Learning diharapkan dapat meningkatkan Aktivitas dan Prestasi Belajar dalam proses pembelajaran Akuntansi melalui aktivitas pemecahan masalah atau kasus Akuntansi yang dapat ditemui siswa dalam kehidupan sehari-hari baik di dunia usaha maupun di dunia industri.

Berdasarkan latar belakang masalah di atas maka dirumuskan judul penelitian "Implementasi Model Problem Based Learning Untuk Meningkatkan Aktivitas Dan Prestasi Belajar Akuntansi Siswa Kelas X AK 3 SMK Muhammadiyah 2 Klaten Utara Tahun Ajaran 2012/2013"

\section{Aktivitas Belajar}

Aktivitas merupakan prinsip yang sangat penting dalam proses pembelajaran. Aktivitas harus dilakukan oleh siswa sebagai usaha untuk meningkatkan hasil belajar.Sardiman (2009: 95-96) berpendapat bahwa tidak ada belajar kalau tidak ada aktivitas.

Aktivitas Belajar merupakan kegiatan fisik dan psikis yang tidak dapat dipisahkan.Aktivitas fisik ditunjukkan melalui gerak siswa dengan anggota badan untuk membuat sesuatu, bermain, atau bekerja, sehingga siswa tidak hanya duduk, mendengarkan, melihat, atau bersikap pasif saja.Siswa dikatakan melakukan aktivitas psikis jika daya jiwanya bekerja sebanyak-banyaknya atau berfungsi dalam rangka pengajaran.

Aktivitas Belajar dalam penelitian ini adalah aktivitas untuk melakukan suatu kegiatan yang mendayagunakan fisik dan psikis untuk mencapai perkembangan kognisi tertentu, dimana siswa diberi kesempatan dalam kelas untuk bertindak aktif.Demikian bisa dilihat bahwa Aktivitas Belajar siswa sangat bervariasi, peran gurulah yang menjamin siswa untuk memperoleh pengetahuan dan keterampilan dalam kondisi yang ada.

Mengajar dalam konteks standar proses pendidikan tidak hanya sekedar menyampaikan materi pelajaran, akan tetapi juga dimaknai sebagai suatu proses mengatur lingkungan supaya siswa belajar.Makna belajar yang demikian sering diistilahkan sebagai pembelajaran. Hal ini mengisyaratkan bahwa dalam proses pembelajaran siswa harus dijadikan sebagai pusat dari kegiatan. Hal ini dimaksudkan untuk membentuk watak, peradaban, dan meningkatkan mutu siswa.

\section{Prestasi Belajar Akuntansi}

Prestasi harus mencerminkan tingkatan-tingkatan siswa sejauh mana telah dapat mencapai tujuan yang ditetapkan setiap bidang studi (Suharsimi, 2006: 276).Prestasi belajar adalah hasil pengukuran yang berwujud angka atau pernyataan yang mencerminkan tingkat penguasaan materi pelajaran (Sugihartono, 2007: 130).

Prestasi Belajar Akuntansi adalah hasil usaha siswa dalam mempelajari mata pelajaran akuntansi di sekolah selama periode tertentu yang dapat dinyatakan dalam bentuk skor atau angka. Jadi, Prestasi Belajar Akuntansi merupakan hasil yang telah dicapai oleh siswa dalam usahanya untuk menguasai akuntansi yang dinyatakan dengan nilai yang diperoleh setelah diadakan evaluasi.

Manfaat Prestasi Belajar adalah dengan adanya Prestasi Belajar di sekolah, dapat membantu siswa dalam menilai dirinya sampai sejauh mana 
kemampuan yang dimilikinya.Prestasi dapat dijadikan sebagai bahan perbandingan seorang siswa untuk mengoreksi kemampuan dirinya dengan siswa-siswa lainnya yang mempunyai prestasi baik di atas atau di bawahnya.

\section{Problem Based Learning(PBL)}

Problem Based Learningadalah suatu pendekatan ke arah penataan pembelajaran yang melibatkan para peserta didik untuk menghadapi permasalahan melalui praktik nyata sensual dengan kehidupan sehari-hari menurut Boud dalam Yatim Riyanto (2010: 285).

Problem Based Learning adalah suatu model pembelajaran yang memfokuskan kegiatan pembelajaran pada penyajian masalah kepada siswa dan kemudian siswa secara aktif memecahkan masalah tersebut melalui serangkaian kegiatan penelitian, pengamatan, dan investigasi berdasarkan teori, konsep, dan prinsip yang telah dipelajari sebelumnya (telah diberikan oleh guru sebelumnya). Rancangan permasalahan yang lazim dialami siswa dalam dunia nyata.

Menurut Dewey dalam Wina Sanjaya (2010:217) terdapat 6 langkah model pembelajaran berdasarkan masalah yaitu:

1) Merumuskan masalah, yaitu langkah siswa menentukan masalah yang akan dipecahkan.

2) Menganalisis masalah, yaitu langkah siswa meninjau masalah secara kritis dri berbagai sudut pandang.

3) Merumuskan hipotesis, yaitu langkah siswa merumuskan berbagai kemungkinan pemecahan masalah sesuai dengan pengetahuan yang dimiliki siswa.

4) Mengumpulkan data, yaitu langkah siswa mencari dan menggambarkan informasi yang diperlukan untuk pemecahan masalah.

5) Pengajuan hipotesis, yaitu langkah siswa mengambil atau merumuskan kesimpulan sesuai dengan penerimaan dan penolakan hipotesis yang diajukan.

6) Merumuskan rekomendasi pemecahan masalah, yaitu langkah siswa menggambarkan rekomendasi yang dapat dilakukan sesuai rumusan hasil pengujian hipotesis dan rumusan kesimpulan

\section{B. Metode Penelitian}

\section{Jenis Penelitian}

Desain penelitian ini adalah penelitian tindakan kelas.Penelitiandilakukan dengan menggunakan siklus menurut model Kemmis \&Taggartyang terdiri dari perencanaan, pelaksanaan, observasi dan refleksi.

\section{Tempat dan Waktu Penelitian}

Penelitian Tindakan Kelas ini dilakukan di SMK Muhammadiyah 2 Klaten Utara Kelas X AK3 Tahun Ajaran 2012/2013.Penelitian ini dilaksanakan pada semester gasal tahun ajaran 2012/2013 yaitu pada bulan November 2012. 


\section{Subjek dan Objek Penelitian}

Subjek penelitian ini adalah Siswa Kelas $X$ AK3 SMK Muhammadiyah 2 Klaten Utara Tahun Ajaran 2012/2013 yang terdiri dari 19 siswa.Objek penelitian ini adalah Aktivitas dan Prestasi Belajar Akuntansi Siswa Kelas X AK 3 SMK Muhammadiyah 2 Klaten Utara Tahun Ajaran 2012/2013.

\section{Teknik Pengumpulan Data}

a. Observasi

Observasi dilakukan pada saat pelaksanaan pembelajaran di kelas tentang Aktivitas Belajar siswa selama pembelajaran berlangsung. Observasi dilakukan dengan menggunakan lembar observasi Aktivitas Belajar siswa yang telah dipersiapkan dan berpedoman pada kriteria penilaian yang disusun sebelumnya.

b. Catatan Lapangan

Catatan lapangan digunakan untuk mendeskripsikan suasana kelas ketika kegiatan pembelajaran sedang berlangsung.

c. Tes

Tes dibuat untuk mengetahui kriteria keberhasilan belajar siswa dalam menguasai materi yang telah disampaikan oleh guru. Tes dilakukan melalui pre-test dan post-test.

d. Dokumentasi

Dalam penelitian ini dokumen yang digunakan adalah daftar nama siswa dan nilai ulangan sebelumnya.

\section{Instrumen Penelitian}

a. Lembar Observasi

Lembar observasi ini berupa catatan pengamatan Aktivitas Belajar siswa selama pembelajaran dengan model Problem Based Learning. Lembar observasi digunakan untuk mengumpulkan data mengenai Aktivitas Belajar siswa dalam proses pembelajaran Akuntansi. Aktivitas Belajar siswa yang diamati meliputi beberapa aspek yang dimodifikasi dari Sardiman (2009: 101) dan Umi Nur Hanifah (2012: 19) yaitu meliputi menjawab pertanyaan, bekerja sama dalam kelompok, melakukan diskusi, mempresentasikan hasil diskusi, mengajukan pertanyaan, dan mengemukakan pendapat. Lembar observasi diisi oleh observer yang bersangkutan. Hasil dari penilaian observer pada lembar observasi yang telah dibuat, dapat digunakan untuk mengetahui kekurangan-kekurangan dalam proses pembelajaran. Melalui lembar observasi tersebut, peneliti mempunyai gambaran untuk memperbaiki rancangan rencana pembelajaran pada tahap refleksi.

b. Catatan Lapangan

Catatan lapangan berupa formulir yang digunakan untuk mencatat segala bentuk Aktivitas Belajar siswa selama proses pembelajaran dengan model Problem Based Learning yang berlangsung di dalam kelas mulai dari siklus I sampai dengan akhir siklus II. 
c. Soal pre-test dan post-test

Pre-test dan post-test pada dasarnya merupakan satu rangkaian dari metode yang akan digunakan pada saat penelitian berlangsung. Pretest dilakukan pada awal proses pembelajaran selama beberapa menit agar siswa memiliki gambaran mengenai materi yang akan dipelajari dan untuk mengetahui kemampuan awal siswa, sedangkan post-test dilakukan pada akhir proses pembelajaran untuk mengetahui sejauh mana kemampuan siswa dalam memecahkan persoalan Akuntansi terhadap materi tersebut.

d. Dokumentasi

Dokumentasi digunakan untuk memberikan gambaran secara jelas mengenai pelaksanaan kegiatan pembelajaran yang terjadi di dalam kelas. Dokumen yang digunakan yaitu daftar nama siswa dan nilai ulangan sebelumnya yang digunakan untuk penentuan kelompok awal.

\section{Prosedur Penelitian}

\section{a. Siklus I}

1) Persiapan tindakan (Planning)

a) Membuat rencana pembelajaran (RPP) dengan Kompetensi Dasar Melakukan Pencatatan Transaksi Dalam Jurnal yang diajarkan dengan model Problem Based Learning (PBL). RPP disusun oleh peneliti dengan pertimbangan dari guru dan dosen yang bersangkutan. RPP ini berguna sebagai pedoman guru dalam melaksanakan kegiatan pembelajaran di kelas.

b) Mempersiapkan lembar observasi dokumen mengenai Aktivitas Belajar siswa.

c) Menyediakan sarana dan media pembelajaran yang akan digunakan dalam setiap pembelajaran.

d) Mempersiapkan soal pre-test untuk siswa yaitu tes yang akan diberikan pada awal pembelajaran dan post-test yang akan diberikan pada akhir siklus. Soal pre-test dan post-test disusun oleh peneliti dengan pertimbangan dari dosen pembimbing dan guru yang bersangkutan.

2) Pelaksanaan tindakan (Acting) dan observasi (Observation)

Tindakan ini dilakukan dengan menggunakan panduan perencanaan yang telah dibuat dan dalam pelaksanaannya bersifat fleksibel dan terbuka terhadap perubahan-perubahan. Selama proses pembelajaran berlangsung, guru mengajar siswa dengan menggunakan RPP menggunakan model Problem Based Learning.

Tahap observasi merupakan kesatuan dari tahap pelaksanaan.Artinya pada saat melakukan tindakan maka peneliti sekaligus mengobservasi jalannya kegiatan. Hasil observasi ini dicatat dalam lembar observasi Aktivitas Belajar siswa.

3) Refleksi (Reflecting)

Pelaksanaan refleksi berupa diskusi antara peneliti dan guru Akuntansi yang bersangkutan. Diskusi tersebut bertujuan untuk melakukan evaluasi hasil tindakan yang telah dilaksanakan yaitu 
dengan melakukan cara penilaian terhadap proses pembelajaran yang terjadi, masalah yang muncul, dan segala hal yang berkaitan dengan tindakan yang dilakukan. Setelah itu mencari solusi terhadap masalah-masalah yang akan timbul dan nantinya akan dilakukan b. Siklus II rencana perbaikan pada siklus berikutnya.

Untuk siklus II, tahapan-tahapan yang diberikan sama dengan Siklus I.AdapunRPP disesuaikan dengan materi.

Hasil refleksi menjadi acuan untuk menentukan rekomendasi tindakan yang akan dilaksanakan pada siklus berikutnya. Siklus II dilaksanakan apabila tindakan Siklus I belum mencapai tujuan penelitian yang diharapkan. Kegiatan pada Siklus II merupakan perbaikan-perbaikan tindakan sesuai rekombinasi Siklus I. Kebutuhan siklus tersebut menyesuaikan kondisi kelas. Apabila masalah di kelas sudah teratasi, maka siklus PTK dapat diakhiri.

\section{Teknik Analisis Data}

a. Analisis Aktivitas Belajar Siswa

Data yang diperoleh dalam penelitian ini berupa lembar pengamatan Aktivitas Belajar siswa yang diamati selama berlangsungnya kegiatan pembelajaran. Data pengamatan yang telah diperoleh dihitung kemudian dipersentase, setelah itu didiskripsikan dalam tabel dan grafik peningkatan Aktivitas Belajar siswa untuk setiap siklusnya. Dengan demikian dapat diketahui sejauh mana peningkatan yang dicapai dalam pembelajaran. Untuk menganalisis keberhasilan berupa Aktivitas Belajar siswa secara kualitatif pada data yang berasal dari lembar observasi Aktivitas Belajar siswa saat pelaksanaan pembelajaran yang dinilai berdasar pedoman penilaian. Persentase skor Aktivitas Belajar pada masing-masing siswa dihitung dengan rumus:

$$
P(\%)=\frac{\text { skoryangdiperolehdarihasilaktivitasbelajar }}{\text { skormaksimum }} \times 100
$$

Persentase banyaknya siswa yang terlibat dalam setiap aspek Aktivitas Belajar dihitung dengan rumus:

$$
P(\%)=\frac{\text { total skoryangdiperolehdari setiap aktivitasbelajar }}{\text { skormaksimum }} \times 100
$$

Pembelajaran dikatakan optimal untuk setiap siklus jika ada peningkatan Aktivitas Belajar siswa jika dibandingkan dengan siklus sebelumnya.

b. Analisis Peningkatan Prestasi Belajar Siswa

Analisis Prestasi Belajar Akuntansi dilakukan dengan mengetahui ketuntasan nilai yang didapat pada tiap akhir siklus dan menghitung banyaknya (persentase) siswa yang tuntas belajar. Persentase siswa yang tuntas belajar dapat dihitung dengan rumus:

$\mathrm{P}=\frac{\mathrm{F}}{\mathrm{N}} \mathrm{x} 100 \%$

Keterangan:

$\mathrm{P}=$ Persentase siswa yang tuntas.

$\mathrm{F}=$ Jumlah siswa yang memperoleh nilai $\geq 75$. 
$\mathrm{N}=$ Jumlah siswa yang mengikuti tes.

(Dimodifikasi dari Djamarah, 2010: 264265)

\section{Indikator Keberhasilan}

Suatu tindakan dikatakan berhasil apabila mampu mencapai kriteria yang telah ditentukan. Dilihat dari segi proses, pembelajaran dikatakan berhasil dan berkualitas apabila seluruhnya atau setidaktidaknya sebagian besar $(75 \%)$ peserta didik terlibat secara aktif, baik fisik, mental, maupun sosial dalam proses pembelajaran (Mulyasa, 2006: 101).Indikator keberhasilan dalam penelitian ini yaitu:

1. Aktivitas Belajar Akuntansi dalam pembelajaran dengan model Problem Based Learning mencapai75\% untuk setiap siswa dan 75\% dari jumlah siswa.

2. Prestasi Belajar Akuntansi mencapai nilai KKM yaitu 75 sebanyak $75 \%$ dari jumlah siswa.

\section{Hasil Penelitian}

\section{Laporan Siklus I}

a. Perencanaan

Proses pembelajaran pada siklus I dilaksanakan dengan menggunakan model Problem Based Learning. Perubahan model pembelajaran yang digunakan ini bertujuan supaya pembelajaran menjadi lebih efektif dan memberikan kesempatan pada siswa untuk terlibat langsung dalam proses pembelajaran, sehingga Aktivitas dan Prestasi Belajar Akuntansi meningkat.

Materi yang diajarkan pada siklus I adalah pencatatan transaksi dalam jurnal umum. Siswa dibagi menjadi 5 kelompok. Masingmasing kelompok terdiri dari dari 3 sampai 4 orang. Pembagian kelompok dilakukan secara heterogen dengan berdiskusi dengan guru pembimbing. Pembagian kelompok didasarkan pada kemampuan kognitif siswa. Harapannya dalam tiap kelompok terdapat pemerataan tingkat kognitif siswa. Instrumen yang digunakan sebagai perangkat pembelajaran adalah Rencana Pelaksanaan pembelajaran (RPP), lembar pembagian kelompok, lembar evaluasi kognitif berupa pre-test dan post-test, lembar observasi Aktivitas Belajar siswa dan catatan lapangan.

b. Tindakan

Peneliti berkolaborasi dengan guru sebagai observer dan pengajar. Sebelumnya guru selaku kolaborator telah diberi pengarahan sebelum melaksanakan pengamatan di lapangan.

Siklus I dalam penelitian ini dilaksanakan dalam dua kali pertemuan. Pertemuan pertama dilaksanakan hari Rabu tanggal 7 November 2012 pukul 11.15-13.30 WIB. Pertemuan pertama dengan alokasi waktu 1x45 menit, 2x30 menit diawali dengan pembukaan dan salam. Dilanjutkan dengan mengecek kehadiran siswa, memberikan pembinaan dan menyampaikan indikator pembelajaran. Setelah itu, 
guru dan peneliti membagikan soal pre-test dan dikerjakan secara mandiri.peneliti dan guru membagi siswa ke dalam 5 kelompok yaitu kelompok A, B, C, D, dan E dengan masing-masing kelompok terdiri atas 3 sampai 4 siswa. Selanjutnya, membagikan soal kelompok untuk dikerjakan dan didiskusikan kepada teman satu kelompok kemudian dipresentasikan di depan kelas.Kelompok yang mempresentasikan hasil diskusi pada pertemuan pertama adalah kelompok $\mathrm{C}$ dan $\mathrm{E}$. Bersamaan dengan pelaksanaan pembelajaran peneliti dan guru secara bersama-sama mengamati Aktivitas Belajar siswa kemudian di nilai dalam lembar observasi Aktivitas Belajar Siswa. Guru memberikan penguatan dan meluruskan materi yang dipresentasikan oleh masingmasing kelompok. Di akhir pembelajaran peneliti dan guru membimbing siswa membuat kesimpulan pembelajaran pada pertemuan hari ini. Guru menyampaikan rencana pembelajaran pada pertemuan berikutnya. Pembelajaran ditutup dengan do'a dan salam.

Pertemuan kedua dilaksanakan hari Jum'at tanggal 9 November 2012 pukul 07.00-08.45 WIB. Pertemuan kedua dengan alokasi waktu $2 \times 45$ menit diawali dengan pembukaan dan salam. Setiap jam pertama sebelum pelajaran dimulai dilakukan doa dan tadarus bersama yang dipandu dari pusat, kurang lebih selama 10 menit. Setelah doa dan tadarus selesai dilanjutkan dengan mengecek kehadiran siswa, memberikan pembinaan dan menyampaikan indikator pembelajaran. Selanjutnya menyampaikan motivasi dan mengulas kegiatan pembelajaran pada pertemuan sebelumnya untuk mengingatkan kembali kepada siswa tentang materi yang telah disampaikan. Siswa diminta untuk berkelompok sesuai dengan kelompoknya masingmasing seperti pada pertemuan sebelumnya. Kelompok yang belum mempresentasikan pada pertemuan sebelumnya diminta untuk mempersiapkan hasil diskusi. Bersamaan dengan pelaksanaan pembelajaran peneliti dan guru secara bersama-sama mengamati Aktivitas Belajar siswa kemudian di nilai dalam lembar observasi Aktivitas Belajar Siswa. Setelah semua kelompok selesai presentasi guru memberikan penguatan dan meluruskan materi yang dipresentasikan oleh masing-masing kelompok. Kegiatan selanjutnya adalah mengerjakan soal post-test.Di akhir pembelajaran peneliti dan guru membimbing siswa untuk menyimpulkan pembelajaran pada pertemuan hari ini. Guru menyampaikan rencana pembelajaran pada pertemuan berikutnya dan tidak lupa meminta siswa untuk belajar dirumah. Pembelajaran ditutup dengan do'a dan salam.

c. Pengamatan

Berdasarkan hasil kegiatan pembelajaran yang telah dideskripsikan diatas, maka diperoleh data Persentase Aktivitas Belajar siswa selama mengikuti kegiatan pembelajaran dengan model Problem based Learning dan data Prestasi Belajar di siklus I sebagai berikut:

1) Diskripsi Aktivitas Belajar Siswa 
Tabel 1.Persentase Aktivitas Belajar Siswa Pada Siklus I

\begin{tabular}{|l|l|c|c|}
\hline No & \multicolumn{1}{|c|}{ Indikator Aktivitas } & $\begin{array}{c}\text { Jumlah } \\
\text { Skor }\end{array}$ & Persentase \\
\hline 1. & Menjawab pertanyaan & 59 & $77,63 \%$ \\
\hline 2. & Bekerja sama dalam kelompok & 55 & $72,37 \%$ \\
\hline 3. & Melaksanakan diskusi & 44 & $57,89 \%$ \\
\hline 4. & Mempresentasikan hasil diskusi & 53 & $69,74 \%$ \\
\hline 5. & Mengajukan pertanyaan & 29 & $38,16 \%$ \\
\hline 6. & Mengemukakan pendapat & 48 & $63,16 \%$ \\
\hline \multicolumn{3}{|c|}{ Rata-rata } & $63,16 \%$ \\
\hline
\end{tabular}

Berdasarkan tabel di atas, aspek menjawab pertanyaan menunjukkan persentase sebesar 77,63\%, sedangkan aspek yang lain persentasenya kurang dari $75 \%$. Jika diamati berdasarkan lembar observasi Aktivitas Belajar siswa yang telah diisi oleh pengamat, sebanyak $36,84 \%$ siswa yang aktif dalam proses pembelajaran. Rendahnya Aktivitas Belajar siswa disebabkan karena pada siklus pertama ini siswa belum terbiasa dengan model Problem Based Learning yang dilakukan dengan diskusi dimana siswa harus menentukan sendiri konsep yang sedang dipelajari. Secara keseluruhan total nilai Aktivitas Belajar siswa menunjukkan pencapaian $63,16 \%$. Untuk itu perlu diadakan perbaikan dan perencanaan tindakan ulang untuk siklus berikutnya.

2) Diskripsi Prestasi Belajar

Prestasi Belajar pada siklus I ini didapat dari pre-test dan post-test pada waktu pembelajaran. Pre-testdilakukan sebelum pembelajaran berlangsung, post-test dilakukan di akhir siklus pembelajaran. Secara singkat nilai pre-test dan post-test siswa kelas X AK 3 SMK Muhammadiyah 2 Klaten Utara pada siklus I disajikan pada Tabel 2.

Tabel 2. Nilai Pre-test dan Post-test siswa

\begin{tabular}{|l|c|c|c|}
\hline No & Keterangan & Pre-test & Post-test \\
\hline 1. & Jumlah siswa & 17 & 19 \\
\hline 2. & Nilai Min & 20 & 62 \\
\hline 3. & Nilai Max & 95 & 100 \\
\hline
\end{tabular}

Selanjutnya Persentase siswa yang berhasil mencapai KKM disajikan pada Tabel 3.

Tabel 3.Persentase Siswa yang Berhasil Mencapai KKM

\begin{tabular}{|l|c|c|c|}
\hline No & Keterangan & Pre-test & Post-test \\
\hline 1. & $\begin{array}{c}\text { Jumlah siswa yang } \\
\text { mencapai KKM }\end{array}$ & 4 & 16 \\
\hline 2. & $\begin{array}{c}\text { Persentase siswa yang } \\
\text { mencapai KKM }\end{array}$ & $23,53 \%$ & $84,21 \%$ \\
\hline
\end{tabular}


Dari Tabel 3 menunjukkan peningkatan Prestasi Belajar yaitu nilai post-test lebih tinggi dari nilai pre-test. Jumlah siswa yang mencapai KKM pada pre-test sebanyak 4 siswa dan pada post-test 16 siswa sehingga persentase siswa yang sudah mencapai KKM pada pre-test $23,53 \%$, pada post-test $84,21 \%$. Hal ini sudah menunjukan keberhasilan tindakan, karena sebanyak $84,21 \%$ siswa mencapai nilai KKM yaitu 75 .

Berdasarkan data pengamatan dan analisis data terhadap proses pelaksanaan pembelajaran melalui model Problem Based Learning dapat dinyatakan pada siklus pertama ini belum mencapai hasil yang maksimal.

\section{d. Refleksi}

Penggunaan model Problem Based Learning pada siklus I belum terlaksana secara optimal. Siswa sudah dapat menemukan jawaban atau solusi atas setiap kasus atau permasalahan yang disajikan, namun belum semua anggota kelompok terlibat secara aktif dalam upaya pemecahan masalah, sehingga belum semua siswa merasakan sendiri atau memperoleh pengalaman memecahkan kasus atau permasalahan yang disajikan. Hal ini disebabkan karena siswa tidak terbiasa mengerjakan soal kasus secara bersama-sama dalam kelompok. Siswa cenderung pasif dan melimpahkan tugas yang diberikan kepada teman satu kelompok yang dianggap mahir dalam menyelesaikan tugas kelompok. Melihat dari beberapa kelemahan dalam pelaksanaan tindakan siklus I, maka diperlukan upaya perbaikan terhadap pelaksanaan pembelajaran model Problem Based Learning agar bisa diterapkan pada siklus II.

\section{Laporan Siklus II}

a. Perencanaan

Proses pembelajaran siklus II merupakan revisi dari siklus I. Proses pembelajaran masih dilakukan dengan model Problem Based Learning. Tidak banyak perubahan kegiatan pembelajaran dalam siklus ini. Hanya saja ada beberapa yang diperbaiki yaitu penekanan terhadap motivasi siswa untuk berperan aktif dalam kegiatan pembelajaran. Guru selalu memantau jalannya kegiatan pembelajaran dan menegur siswa yang tidak mau bekerja sama dalam kelompok. Materi pada kegiatan pembelajaran pada siklus ini adalah Melakukan Pencatatan Transaksi dalam Jurnal Khusus.

b. Tindakan

Pembelajaran pada siklus ini dilaksanakan pada 2 kali pertemuan. Pembagian kelompok tidak ada perubahan, yaitu tetap sama dengan kelompok pada siklus I.

Pertemuan pertama dilaksanakan hari Selasa, tanggal 13 November 2012 pukul 07.00-08.45 WIB. Pertemuan kedua dengan alokasi waktu $2 \times 45$ menit diawali dengan pembukaan dan salam. Sebelum pelajaran dimulai dilakukan doa dan tadarus bersama yang dipandu dari pusat, kurang lebih selama 10 menit. Dilanjutkan dengan mengecek kehadiran siswa, memberikan pembinaan dan 
menyampaikan indikator pembelajaran. Pada pertemuan pertama siswa masuk semua. Setelah itu, guru dan peneliti membagikan soal pre-test. Selanjutnya, siswa diberikan suatu permasalahan yaitu yang berhubungan dengan pencatatan dalam jurnal khusus. Siswa sangat antusias menjawab pertanyaan. Peneliti dan Guru membagikan soal kelompok untuk dikerjakan dan didiskusikan kepada teman satu kelompok kemudian dipresentasikan di depan kelas. Kelompok yang mempresentasikan hasil diskusi pada pertemuan pertama adalah kelompok B. Guru memberikan penguatan dan meluruskan materi yang dipresentasikan oleh masing-masing kelompok. Pertemuan pertama ini hanya kelompok B yang mempresentasikan hasil diskusi, karena waktu pembelajaran sudah habis. Di akhir pembelajaran peneliti dan guru membimbing siswa membuat kesimpulan pembelajaran pada pertemuan hari ini. Guru menyampaikan rencana pembelajaran pada pertemuan berikutnya dan tidak lupa meminta siswa untuk belajar dirumah. Pembelajaran ditutup dengan do'a dan salam.

Pertemuan kedua dilaksanakan hari Rabu tanggal 14 November 2012 pukul 11.15-13.30 WIB. Pada pertemuan kedua dengan alokasi waktu 1x45 menit, 2x30 menit diawali dengan pembukaan dan salam.Dilanjutkan dengan mengecek kehadiran siswa, memberikan pembinaan dan menyampaikan indikator pembelajaran. Pada pertemuan kedua siswa masuk semua. Guru meminta masing-masing kelompok untuk mempersiapkan presentasi bagi yang belum presentasi. Setelah semua kelompok selesai presentasi guru memberikan penguatan dan meluruskan materi yang dipresentasikan oleh masing-masing kelompok.Guru memberi kesempatan kepada siswa untuk bertanya apabila masih ada penjelasan yang masih kurang paham. Kegiatan selanjutnya adalah mengerjakan soal post-test.Di akhir pembelajaran peneliti dan guru membimbing siswa membuat kesimpulan pembelajaran pada materi yang telah disampaikan. Guru menyampaikan rencana pembelajaran pada pertemuan berikutnya dan tidak lupa meminta siswa untuk belajar dirumah. Pembelajaran ditutup dengan do'a dan salam.

c. Pengamatan

Berdasarkan hasil kegiatan pembelajaran yang telah dideskripsikan di atas, maka diperoleh data Persentase Aktivitas Belajar siswa selama mengikuti kegiatan pembelajaran dan data Prestasi Belajar berupa nilai pre-test dan post-test di siklus II sebagai berikut:

1) Diskripsi Aktivitas Belajar Siswa

Tabel 4.Persentase Aktivitas Belajar Siswa Pada Siklus II

\begin{tabular}{|l|l|c|c|}
\hline No & \multicolumn{1}{|c|}{ Indikator Aktivitas } & $\begin{array}{c}\text { Jumlah } \\
\text { Skor }\end{array}$ & Persentase \\
\hline 1. & Menjawab pertanyaan & 62 & $81,58 \%$ \\
\hline 2. & Bekerja sama dalam kelompok & 65 & $85,53 \%$ \\
\hline 3. & Melaksanakan diskusi & 67 & $88,16 \%$ \\
\hline
\end{tabular}




\begin{tabular}{|l|l|l|l|}
\hline 4. & Mempresentasikan hasil diskusi & 62 & $81,58 \%$ \\
\hline 5. & Mengajukan pertanyaan & 59 & $77,63 \%$ \\
\hline 6. & Mengemukakan pendapat & 66 & $86,84 \%$ \\
\hline \multicolumn{2}{|c|}{ Rata-rata } & $83,55 \%$ \\
\hline
\end{tabular}

Berdasarkan tabel di atas, semua aspek Aktivitas Belajar siswa menunjukkan persentase lebih dari $75 \%$. Jika diamati berdasarkan lembar observasi Aktivitas Belajar siswa yang telah diisi oleh pengamat, sebanyak $89,47 \%$ siswa yang aktif dalam proses pembelajaran. Secara keseluruhan total nilai Aktivitas Belajar siswa menunjukkan pencapaian $83,55 \%$.

2) Diskripsi Prestasi Belajar Siklus II

Tabel 5. Nilai Pre-test dan Post-test siswa

\begin{tabular}{|l|c|c|c|}
\hline No & Keterangan & Pre-test & Post-test \\
\hline 1. & Jumlah siswa & 19 & 19 \\
\hline 2. & Nilai Min & 50 & 90 \\
\hline 3. & Nilai Max & 82 & 100 \\
\hline
\end{tabular}

Selanjutnya Persentase siswa yang berhasil mencapai KKM disajikan pada Tabel 6 .

Tabel 6.Persentase Siswa yang Berhasil Mencapai KKM

\begin{tabular}{|l|c|c|c|}
\hline No & Keterangan & Pre-test & Post-test \\
\hline 1. & $\begin{array}{c}\text { Jumlah siswa yang } \\
\text { mencapai KKM }\end{array}$ & 1 & 19 \\
\hline 2. & $\begin{array}{c}\text { Persentase siswa } \\
\text { yang mencapai } \\
\text { KKM }\end{array}$ & $5,26 \%$ & $100 \%$ \\
\hline
\end{tabular}

Dari Tabel 6 menunjukkan peningkatan prestasi belajar yaitu nilai post-test lebih tinggi dari nilai pre-test. Jumlah siswa yang mencapai KKM pada pre-test sebanyak 1 siswa dan pada post-test 19 siswa sehingga persentase siswa yang sudah mencapai KKM pada pre-test $5,26 \%$, pada post-test $100 \%$. Hal ini sudah menunjukan keberhasilan tindakan, karena sebanyak 100\% siswa

d. Refleksi mencapai nilai KKM yaitu 75 .

Penggunaan model Problem Based Learning pada siklus II sudah terlaksana dengan baik. Hal ini dapat diketahui dengan melihat persentase kenaikan Aktivitas dan Prestasi Belajar siswa dari siklus I. Antusiasme siswa dalam mengikuti kegiatan pembelajaran sudah mengalami peningkatan. Terlihat dari peran aktif siswa dalam melakukan kegiatan pembelajaran yang terekam dalam lembar observasi. Siswa yang dalam siklus I terlihat kurang percaya diri dan kurang aktif, pada siklus II mulai menunjukan percaya diri dan keaktifannya. Siswa juga sudah mulai bertanggung jawab dan percaya 
diri saat mempresentasikan hasil diskusi dalam kelompoknya. Terlihat antar kelopok bersaing untuk mendapat hasil yang terbaik.

Berdasarkan refleksi siklus II, maka penelitian dihentikan di siklus II ini karena sudah terdapat peningkatan Aktivitas dan Prestasi Belajar siswa. Peningkatan tersebut sudah mencapai indikator keberhasilan dalam metode penelitian, yaitu Aktivitas Belajar Akuntansi dalam pembelajaran dengan model Problem Based Learning mencapai $75 \%$ untuk setiap siswa dan $75 \%$ dari jumlah siswa dan Prestasi Belajar Akuntansi mencapai nilai KKM yaitu 75 sebanyak $75 \%$ dari jumlah siswa.

\section{Analisis Data dan Pembahasan}

a. Peningkatan Aktivitas Belajar Siswa

Peningkatan Aktivitas Belajar siswa dari pra siklus ke siklus I hingga siklus II tampak pada hasil penelitian yang telah dilaksanakan. Untuk lebih jelasnya data peningkatan nilai Aktivitas Belajar siswa disajikan dalam Tabel 7 berikut:

Tabel 7. Peningkatan Persentase Hasil Pengamatan Aktivitas Belajar Siswa

\begin{tabular}{|l|l|c|c|c|}
\hline No & Indikator Aktivitas Belajar & Pra Siklus & Siklus I & Siklus II \\
\hline 1. & Menjawab pertanyaan & $15,79 \%$ & $77,63 \%$ & $81,58 \%$ \\
\hline 2. & Bekerja sama dalam kelompok & - & $72,37 \%$ & $85,53 \%$ \\
\hline 3. & Melaksanakan diskusi & - & $57,89 \%$ & $88,16 \%$ \\
\hline 4. & Mempresentasikan hasil diskusi & - & $69,74 \%$ & $81,58 \%$ \\
\hline 5. & Mengajukan pertanyaan & - & $38,16 \%$ & $77,63 \%$ \\
\hline 6. & Mengemukakan pendapat & - & $63,16 \%$ & $86,84 \%$ \\
\hline \multicolumn{2}{r|}{ Rata-rata } & $15,79 \%$ & $\mathbf{6 3 , 1 6 \%}$ & $\mathbf{8 3 , 5 5 \%}$ \\
\hline
\end{tabular}

Dari Tabel 7 menunjukkan peningkatan Aktivitas Belajar siswa secara keseluruhan mulai dari pra siklus ke siklus I dan dari siklus I ke siklus II. Pada siklus II Aktivitas Belajar siswa menunjukkan persentase lebih dari $75 \%$ dan berdasarkan lembar observasi Aktivitas Belajar siswa sebanyak 89,47\% siswa yang aktif dalam proses pembelajaran. Secara keseluruhan total nilai Aktivitas Belajar siswa menunjukkan pencapaian $83,55 \%$.

Peningkatan juga terjadi pada Aktivitas Belajar untuk setiap siswa, pada pra siklus sebanyak $15,79 \%$ siswa yang aktif dalam proses pembelajaran, siklus I sebanyak $36,84 \%$ siswa dan siklus II sebanyak $89,47 \%$. Hal ini menunjukkan peningkatan sebesar $21,05 \%$ dari pra siklus ke siklus I dan sebesar 52,63\% dari siklus I ke siklus II.

b. Peningkatan Prestasi Belajar Siswa

Keberhasilan Prestasi Belajar dari tindakan yang diberikan dapat dilihat dari hasil pekerjaan siswa yaitu pre-test dan post-test. Adapun rangkuman pencapaian siswa dapat dilihat pada tebel 8 . 
Tabel 8. Pencapaian Nilai Kognitif Siswa

\begin{tabular}{|c|c|c|c|c|c|}
\hline Siklus & $\begin{array}{c}\text { Jenis } \\
\text { Test }\end{array}$ & $\begin{array}{c}\text { Nilai } \\
\text { Min }\end{array}$ & $\begin{array}{c}\text { Nilai } \\
\text { Maks }\end{array}$ & $\begin{array}{c}\text { Nilai yang } \\
\text { mencapai } \\
\text { KKM }\end{array}$ & $\begin{array}{c}\text { Persentase } \\
\text { yang mencapai } \\
\text { KKM }\end{array}$ \\
\hline \multirow{2}{*}{ Pra } & Post-test & 10 & 100 & 9 & $47 \%$ \\
\hline \multirow{2}{*}{ II } & Pre-test & 20 & 95 & 4 & $23,53 \%$ \\
\cline { 2 - 6 } & Post-test & 62 & 100 & 16 & $84,21 \%$ \\
\cline { 2 - 6 } & Pre-test & 50 & 82 & 1 & $5,26 \%$ \\
\hline
\end{tabular}

Selama proses pembelajaran Akuntansi mulai dari siklus I sampai dengan siklus II, peneliti telah menunjukkan tindakantindakan yang memang seharusnya dilakukan dalam penerapan model Problem Based Learning. Hampir sebagian besar rencana tindakan yang telah tersusun dalam RPP, dapat dilaksanakan dengan baik dalam praktik pembelajaran. Secara umum, berdasarkan tindakan yang dilakukan setiap siklus keseluruhan aspek yang berhasil teramati melalui instrumen yang telah diisi pengamat dan analisis data pada setiap siklus, ternyata pembelajaran siklus II yang telah berhasil mengatasi kelemahan-kelemahan yang ada pada siklus sebelumnya. Hal ini terlihat dari penilaian Aktivitas Belajar dan jumlah siswa yang terlibat pada siklus II lebih tinggi. Prestasi Belajar dari siklus I dan II terjadi peningkatan dan penelitian dinyatakan berhasil pada siklus II.

Sesuai dengan indikator keberhasilan dalam metodologi penelitian, Aktivitas Belajar Akuntansi dalam pembelajaran dengan model Problem Based Learning mencapai mencapai 75\% untuk setiap siswa dan $75 \%$ dari jumlah siswa dan Prestasi Belajar Akuntansi mencapai nilai KKM yaitu 75 sebanyak 75\% dari jumlah siswa. Dengan demikian, dapat dinyatakan bahwa implementasi model Problem Based Learning dalam pembelajaran Akuntansi telah mampu meningkatkan Aktivitas dan Prestasi Belajar Akuntansi siswa kelas X AK 3 SMK Muhammadiyah 2 Klaten Utara.

\section{Penutup}

\section{Simpulan}

Berdasarkanhasil penelitian dan pembahasan maka penelitian yang telah dilaksanakan di kelas X AK 3 SMK Muhammadiyah 2 Klaten Utara ini dapat disimpulkan sebagai berikut:

a. Penggunaan model Problem Based Learning dalam mata pelajaran Akuntansi di kelas X AK 3 Tahun Ajaran 2012/2013 dapat meningkatkan Aktivitas Belajar siswa yaitu:menjawab pertanyaan, bekerja sama dalam kelompok, melaksanakan diskusi, mempresentasikan hasil diskusi, mengajukan pertanyaan, dan mengemukakan pendapat. Hal ini terbukti dengan adanya peningkatan keseluruhan Aktivitas Belajar siswa dari pra siklus ke siklus I dan dari siklus 1 ke siklus II. Pada siklus I yang menunjukkan Aktivitas Belajar sebanyak $36,84 \%$ siswa, pada siklus II sebanyak $89,47 \%$. 
b. Penggunaan model Problem Based Learning dalam mata pelajaran Akuntansi di kelas X AK 3 Tahun Ajaran 2012/2013 dapat meningkatkan Prestasi Belajar Akuntansi. Hal ini terbukti pada siklus I dan II siswa yang mendapat nilai $\geq 75$ atau mencapai KKM lebih dari $75 \%$, yaitu sebesar $84,21 \%$ pada siklus I dan $100 \%$ pada siklus II.

\section{Keterbatasan Penelitian}

Terdapat beberapa keterbatasan yang dapat mempengaruhi penelitian tindakan kelas ini yaitu:

a. Pertemuan hanya dilakukan dalam 2 siklus. Hal ini dikarenakan keterbatasan waktu yang diberikan oleh pihak sekolah, sehingga tidak menutup kemungkinan data yang diambil oleh peneliti belum memadai.

b. Pada pertemuan pertama ada dua siswa yang tidak hadir. Hal ini menyebabkan siswa yang tidak hadir tidak dapat mengikuti pre-test dan juga mengurangi jumlah anggota kelompok yang sudah ditentukan.

c. Proses diskusi yang kurang terarah menyebabkan cukup banyak waktu yang digunakan menjadi tidak efisien, sehingga Aktivitas dan Prestasi Belajar siswa kurang maksimal.

\section{Saran}

Berdasarkan keterbatasan penelitian maka beberapa saran yang diusulkan adalah sebagai berikut:

a. Bagi siswa

Siswa hendaknya dapat mengikuti setiap tahap dalam proses pembelajaran model Problem Based Learning, karena hal ini sangat bermanfaat bagi peningkatan kemampuan siswa agar senantiasa aktif dalam proses pembelajaran di dalam kelas yang akhirnya akan meningkatkan Prestasi Belajar siswa.

b. Bagi guru

Penerapan model Problem Based Learning dapat diterapkan pada materi lain dengan melihat karakteristik materi dan waktu yang tersedia. Guru dapat mendorong siswa untukmenyelesaikan masalah dengan membiasakan untuk melatih siswa.

c. Bagi peneliti

Model Problem Based Learning dapat meningkatkan hasil belajar Akuntansi aspek kognitif, namun untuk penelitian lebih lanjut dapat dilakukan penelitian untuk mengetahui peningkatan aspek afektifdan aspek sosial siswa terkait dengan pelaksanaan model pembelajaran Problem Based Learning.

\section{E. Daftar Pustaka}

Anas Sudijono.(2007). Pengantar Evaluasi Pendidikan. Jakarta: PT Grafindo Persada. 
Arends, Richard I. (2008). Learning To Teach: Belajar untuk Mengajar terjemahan dari Learning To Teacholeh Helly Prajitno Soetjipto danMulyantini Soetjipto. Yogyakarta: Pustaka Pelajar.

Paramita Ika Sari. (2010). Penerapan Model Problem Based Learning Untuk Meningkatkan Keaktifan dan Hasil Belajar Geografi Siswa di MAN 1 Yogyakarta.Skripsi: FISE UNY.

Haryono Yusuf. (2005). Dasar-Dasar Akuntansi. Yogyakarta: Bagian Penerbitan Sekolah Tinggi Ilmu Ekonomi YKPN.

Hendri Somantri. (2004). Memahami Siklus Akuntansi Perusahaan Jasa DanDagang. Bandung: CV Armico.

Muhibbin Syah. (2011). Psikologi Belajar. Jakarta: PT Raja Grafindo Persada. Mulyasa.(2006). Kurikulum Berbasis Kompetensi. Bandung: PT Remaja Rosdakarya.

Ngalim Purwanto. (2004). Psikologi Pendidikan. Bandung: PT Remaja Rosdakarya.

Nur Erlina Harismawati. (2010). Implementasi Problem Based Learning Dan Penggunaan Modul Akuntansi Bilingual Sebagai Media Pembelajaran Untuk Meningkatkan Prestasi Belajar Akuntansi Siswa Pada Kompetensi Praktik Akuntansi Manual (Perusahaan Jasa) Kelas X.1 Program Keahlian Akuntansi SMK Negeri 1 Yogyakarta Tahun Ajaran 2009/2010. Skripsi:FISE UNY.

OemarHamalik. (2011). Proses Belajar Mengajar. Jakarta: PT Bumi Aksara.

Sardiman A.M. (2009). Interaksi dan Motivasi Belajar Mengajar. Jakarta: PT Raja Gravindo Persada.

Setyorini.(2011). "Penerapan Model Problem Based Learning untuk Meningkatkan Kemampuan Berpikir Kritis Siswa SMP.’Jurnal Pendidikan Fisika Indonesia (Nomor 7). Hlm: 52-56.

Slameto.(2010). Belajar dan Faktor-Faktor Yang Mempengaruhi. Jakarta: Rineka Cipta.

Sugihartono dkk.(2007). Psikologi Pendidikan. Yogyakarta: UNY Press.

Suharsimi Arikunto. (2006). Prosedur Penelitian Suatu Pendekatan Praktik Jakarta: PT Rineka Cipta.

Aksara. (2008). Penelitian Tindakan Kelas. Jakarta: PT Bumi (2009). Dasar-Dasar Evaluasi Pendidikan. Jakarta: PT Bumi Aksara.

Sutratinah Tirtonegoro. (2001). Anak Supernormal dan Program Pendidikannya. Jakarta: PT Bumi Aksara.

Syaiful Bahri Djamarah. (2010). Guru dan Anak Didik Dalam Interaksi Edukatif. Jakarta: PT Rineka Cipta.

Trianto.(2010). Mendesain Model Pembelajaran Inovatif-Progresif. Jakarta: Kencana.

Toto Sucipto. (2009). Akuntansi 1 Untuk Kelas X SMK. Jakarta: Yudhistira.

Umi Nur Hanifah. (2012).Upaya untuk Meningkatkan Aktivitas dan Hasil Belajar IPA Melalui Model Problem Based Learning pada Tema Mata sebagai Alat Optik Bagi Siswa Kelas VIII SMP Negeri 3 Ngaglik. Skripsi: FMIPA UNY. 
Jurnal Pendidikan Akuntansi Indonesia, Vol. XI, No. 1, Tahun 2013

Choirun Nisak \& Annisa Ratna Sari

Halaman 82 - 99

Uzer Usman. (2006). Menjadi Guru Profesional. Bandung: PT Remaja Rosdakarya.

Wagiran.(2007). Strategi Pembelajaran Berorientasi Standar Proses Pendidikan. Jakarta: Prenada Media Group.

Wina Sanjaya. (2010). Strategi Pembelajaran. Jakarta: Prenanda Media Group. 